Syntax Idea: p-ISSN: 2684-6853 e-ISSN: 2684-883X

Vol. 3, No. 2, Februari 2021

\title{
OVERVIEW ANALISIS SISTEM MANAJEMEN KESELAMATAN PADA INDUSTRI PERTAMBANGAN DI BEBERAPA NEGARA
}

\author{
Hertanti Kusuma Wardani dan Nur Khamim \\ Universitas Pembangunan Nasional (UPN) Yogyakarta, Indonesia \\ Email: 212190022@student.upnyk.ac.id dan nurkhamim@upnyk.ac.id
}

\begin{abstract}
The effort to reduce and eliminate the dangers of mining activities by preventing losses that is by implementing the application of safety management. Safety management systems are applied throughout the world. The world gets permission for industrial safety and health to get occupational safety and health. This safety management system is not only applied in Indonesia but also applied in several other countries such as South Korea, Singapore, Malaysia and Australia. In this study an analysis of the differences in the safety management system in these countries with an outline with the aim to carry out an analysis of the safety management system in large rock countries. The comparison obtained from the management system required and applied by the government regarding the safety system in these countries. For Indonesia and Singapore, a safety management system must be implemented in industrial companies, whereas for countries such as South Korea the safety management system is voluntary in other words the safety management system is implemented voluntarily by the industry. Australia is more applying safety management system standards and references for industrial needs. Safety management systems in Australia, South Korea and Malaysia are being readjusted to suit industry needs.
\end{abstract}

Keywords: safety management system; mandatory; voluntary; standard

\section{Abstrak}

Upaya untuk mengurangi dan menghilangkan bahaya dari kegiatan pertambangan dengan melakukan loss prevention yakni dengan adanya penerapan sistem manajemen keselamatan. Sistem manajemen keselamatan diterapkan di seluruh dunia. Dunia semakin menetapkan pedoman untuk keselamatan dan kesehatan industri untuk mempromosikan keselamatan dan kesehatan kerja. Sistem manajemen keselamatan ini bukan hanya diterapkan di Indonesia namun juga diterapkan di beberapa negara lainnya seperti Korea Selatan, Singapura, Malaysia dan Australia. Penelitian ini dilakukan dengan menganalisis perbedaan sistem manajemen keselamatan di negara-negara tersebut secara garis besar dengan tujuan untuk melakukan analisis perbandingan sistem manajemen keselamatan di bebagai negara secara garis besar. Perbandingan yang diperoleh yakni sistem manajemen terdapat pada penerapan yang dilakukan dan peraturan pemerintah mengenai sistem keselamatan di negara-negara ini. Untuk Indonesia dan Singapura, sistem manajemen keselamatan wajib diimplementasikan di perusahaan industri, sedangkan untuk negara seperti Korea selatan sistem manajemen keselamatannya bersifat voluntary dengan kata lain sistem manajemen keselamatan diterapkan secara sukarela oleh indusrti. Australia lebih menerapkan standar dan referensi 
sistem manajemen keselamatan untuk kebutuhan industri. Sistem manajemen keselamatan di Australia, Korea Selatan dan Malaysia disesuaikan kembali dengan kebutuhan industri.

Kata kunci: Sistem manajemen keselamatan; mandatory; voluntary; standar

\section{Pendahuluan}

Pertambangan, menurut Undang-Undang Nomor 3 tahun 2020 tentang Pertambangan Mineral dan Batubara adalah sebagian atau seluruh tahapan kegiatan dalam rangka pengelolaan dan pengusahaan mineral atau batubara yang meliputi penyelidikan umum, eksplorasi, studi kelayakan, konstruksi, penambangan, pengolahan dan/atau pemurnian atau pengembangan dan/atau pemanfaatan, pengangkutan dan penjualan, serta kegiatan pascatambang (UU RI, 2020).

Industri pertambangan sangat memiliki resiko dan bahaya yang besar, resiko dan faktor bahaya yang besar ini terdapat dalam kegiatan pertambangan dimulai dari awal perencanaan hingga akhir tambang dan juga industri pertambangan ini dikenal dengan industri yang memiliki modal dan teknologi yang padat (Setianingrum \& Susilowati, 2020).

Setiap kegiatan produksi dalam pertambangan memiliki resiko tinggi terhadap besarnya potensi bahaya yang dapat menimbulkan kecelakan dan penyakit akibat kerja yang menimpa pekerja dan peralatan tambang. Hal ini sangat mempengaruhi keberlangsungan kegiatan usaha pertambangan (S.Suhardianto, 2009). Resiko kecelakaan dan penyakit akibat kerja tersebut yang bisa terjadi dimana saja, kapan saja dan menimpa siapa saja serta terdapat penyebabnya. Pengendalian dan pengawasan sangat dibutuhkan oleh sistem manajemen keselamatan sebagai acuan dan tonggak dalam pelaksanaan pertambangan guna menciptakan pertambangan yang baik (good mining practice), (Suryosagoro, Laksito, \& Sugiyarto, 2013).

Dunia semakin menetapkan pedoman untuk keselamatan dan kesehatan industri untuk mempromosikan keselamatan dan kesehatan kerja (Kim \& Kim, 2012). Sistem manajemen keselamatan ini bukan hanya diterapkan di Indonesia namun juga diterapkan di beberapa negara lainnya seperti Korea Selatan, Singapura, Malaysia dan Australia. Tujuan utama sistem keselamatan ini yakni pengendalian resiko dari bahaya dan kecelakaan (loss prevention).

Perbandingan sistem manajemen keselamatan yang banyak dilakukan yakni membandingkan sistem manajemen keselamatan pada dua perusahaan menggunakan sistem manajemen yang sama (Setiowati.Wiwik, 2008) dan perbandingan antara 2 jenis sistem manajemen yang berbeda pada satu perusahaan (Nurcahyo.Y,2007). Penelitian ini bertujuan untuk melakukan analisis perbandingan sistem manajemen keselamatan pada industry pertambangan di berbagai negara secara garis besar.

\section{Metode Penelitian}

Jenis penelitian yan diterapkan dalam penelitian ini adalah penelitian kepustakaan atau libraray research atau literature review. Teknik pengambilan data dilakukan 
dengan pemilihan literatur dari berbagai sumber kemudian dikembangkan dengan membuat pertanyaan penelitian (research question) yang sesuai dengan kata kunci yakni sistem manajemen keselamatan, mandatory, voluntary dan standar manajemen keselamatan agar sesuai dengan informasi yang dibutuhkan. Setelah itu, dilakukan analisis mengenai informasi yang didapatkan yang telah disesuaikan dengan kata kunci.

Penulis merangkum metodologi dan tahapan penelitian dalam bentuk bagan alir berdasarkan studi literatur baik dari jurnal nasional, jurnal intenasional maupun thesis (Gambar 1). Penelitian ini diharapkan dapat menyimpulkan perbedaan dari sistem manajemen keselamatan yang ada di berbagai negara yakni Indonesia, Korea Selatan, Singapura, Malaysia dan Australia.

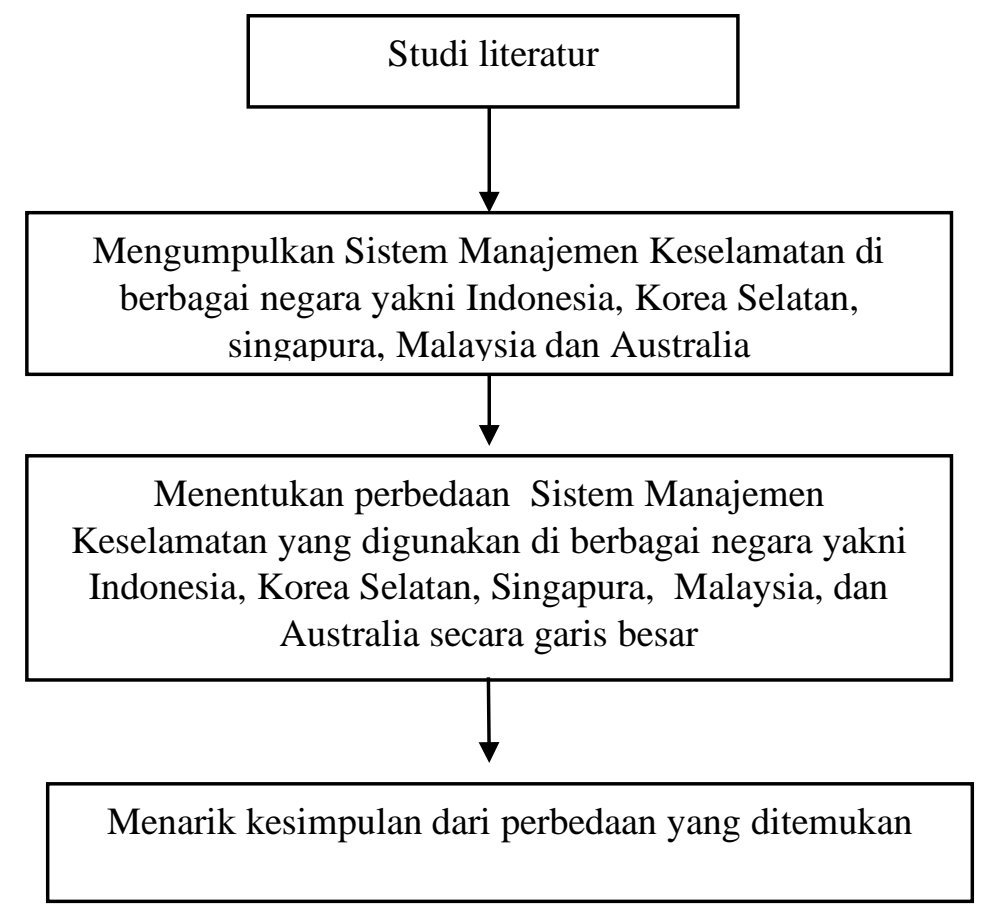

\section{Gambar 1 \\ Diagram alir penelitian}

\section{Hasil dan Pembahasan}

Sistem manajemen keselamatan pertambangan yang diterapakan di beberapa negara diantaranya sebagai berikut :

\section{Sistem Manajemen Keselamatan di Indonesia}

Sistem Manajemen Keselamatan Pertambangan di Indonesia bersifat mandatory yang telah diatur dalam kebijakan pemerintah yakni Sistem Manajemen Keselamatan dan kesehatan kerja (SMK3) dalam Peraturan Pemerintah No. 50 tahun 2012 (Situmorang, 2012) dan sistem manajemen keselamatan pertambangan (SMKP) Mineral dan Batubara dalam Peraturan Menteri ESDM No. 28 tahun 2014 (Kementerian Kesehatan Republik Indonesia, 2014). SMKP merupakan Sistem manajemen yang menjadi bagian dari sistem manajemen perusahaan dalam rangka mengendalikan risiko keselamatan pertambangan yang terdiri dari $\mathrm{K} 3$ pertambangan 
dan keselamatan operasi pertambangan (K3 Pertambangan dan KO Pertambangan) (Sholihah, 2018).

Ada 7 elemen dalam SMKP Minerba yang harus diterapkan yakni :

1. Kebijakan

2. Perencanaan

3. Organisasi dan personel

4. Implementasi

5. Pemantauan, evaluasi dan tindak lanjut

6. Dokumentasi

7. Tinjauan manajemen dan peningkatan kinerja.

Dari masing-masing elemen akan dilakukan pembobotan berdasarkan kepentingan dari masing-masing elemen untuk dilakukan penilaian. Penilaian atau dengan kata lain audit untuk penerapan SMKP di perusahaan dilakukan dengan mengambil sampel dari masing-masing elemen dari setiap area kegiatan berdasarkan kebijakan auditor dengan menggunakan metode penilaian draft (G.Sumarno, 2018), (Markkanen, 2004).

Untuk Sertifikasi SMKP dapat dilakukan di CV atau lembaga terkait yangn telah mendapatkan sertifikasi dalam training SMKP. Contohnya perusahaanperusahaan jasa konsultan.

\section{Sistem Manajemen Keselamatan di Korea Selatan}

Korea Selatan menerapkan sistem manajemen dengan nama KOSHA 18001dan OHSAS 18001 yang bersifat voluntary. KOSHA 18001 yakni Korea Occupational Safety and Health Administration 18001. KOSHA adalah organisasi pemerintah yang memiliki kepercayaan publik, membayar subsidi untuk sertifikasi, dan memiliki hubungan langsung atau tidak langsung dengan tempat kerja tentang keselamatan dan kesehatan. Selain itu, banyak bisnis ekspor memperoleh OHSAS 18001 dan KOSHA 18001. KOSHA 18001 terdiri dari 3 bagian yakni sistem manajemen keselamatan \& kesehatan, tingkat aktivitas keselamatan dan kesehatan dan wawancara keselamatan dan kesehatan sebagai panduan dalam pelaksanaan sistem manajemen keselematan di Korea Selatan (Lee, Kim, \& Kim, 2012).

Sertifikasi KOSHA 18001 mencakup penilaian diri terhadap keselamatan dan kesehatan tempat kerja yang menerapkan, keselamatan dan kegiatan kesehatan kerja, dan wawancara dengan manajer keselamatan dan kesehatan yang komprehensif. Selain itu, sertifikasi lainnya dibagi menjadi konsultasi sertifikasi dan sertifikasi itu sendiri. Namun, seluruh proses sertifikasi KOSHA 18001 hanya dilakukan oleh KOSHA.

OHSAS 18001 adalah suatu standar internasional kesehatan dan keselamatan kerja yang diakui oleh internasional. Perbedaan OHSAS 18001 dan KOSHA 18001 yakni KOSHA 18001 terdiri dari 3 bagian : keselamatan dan kesehatan sistem manajemen; tingkat aktivitas keselamatan dan kesehatan dan keamanan dan wawancara kesehatan. Sementara itu, OHSAS 18001 hanya memiliki keamanan dan sistem manajemen kesehatan. 
Penilaian diri tentang keselamatan \& kesehatan kerja yaitu termasuk hanya dalam KOSHA 18001 disiapkan oleh pelamarperusahaan dengan formulir aplikasi dan diserahkan ke KOSHA. Sementara itu, kegiatan keselamatan \& kesehatan kerja dievaluasidibuat oleh petugas penilai selama penilaian. Bagan penilaian aktivitas keselamatan \& kesehatan kerja disiapkan sesuai dengan standar yang diperlukan dari Keselamatan Industri dan Undang-undang Kesehatan, jadi seharusnya tidak ada pelanggaran terhadap Keselamatan Industri dan UU Kesehatan untuk mendapatkan akreditasi. Alasannya sepertinya KOSHA Sistem sertifikasi 18001 dikembangkan dan diterapkan ke tempat kerja oleh organisasi pemerintah. Ada dua sistem yakni satu untuk industri konstruksi dan lainnya untuk industri kecil dan menengah tempat kerja, yang terakhir umumnya sama kecuali untuk beberapa detail.

Standar penilaian untuk OHSAS 18001 adalah sama untuk skala dan klasifikasi tempat kerja yang menerapkan. Hanya sistem manajemen keselamatan dan kesehatan yang dinilai di Indonesia OHSAS 18001, jadi tidak ada banyak batasan dalam ukuran dan Klasifikasi tempat kerja yang melamar, yang bisa faktor utama dalam KOSHA 18001 (Lee et al., 2012).

Sebagai tambahan program KOSHA 2000 juga diterapkan di Korea Selatan dengan lingkup yang lebih detail yakni implementasi manajemen resiko. KOSHA mengimplementasikan program manajemen risiko di tempat kerja seperti program KOSHA 2000, yang dirancang untuk mengurangi cedera dan dioperasikan secara sukarela. Namun, karena penerapan program ini tidak wajib, itu umumnya diterapkan pada perusahaan besar yang mempertahankan kondisi keamanan yang relatif baik dan dapat membayar biaya program. ntuk mencapai efek terbaik dalam mengurangi cedera kerja, perangkat kebijakan diperlukan tidak hanya untuk meningkatkan efisiensi dan kredibilitas pemeriksaan keselamatan itu sendiri, tetapi juga untuk menerapkan program pemeriksaan keselamatan wajib di area kerja.

\section{Sistem Manajemen Keselamatan di Singapura}

Sistem manajemen keselamatan di Singapura menerapkan regulasi atau peraturan dari pemerintah yang sifatnya mandatory yang diatur dalam perundangundangan di Singapura dalam Workplace Safety and Health (Safety and Health Management System and Auditing) Regulations 2009. Kerangka kerja keselamatan dan kesehatan kerja aau Workplace Safety and Health (WSH) Singapura memandu pengelolaan WSH oleh semua pemangku kepentingan - pemerintah, industri, serta karyawan. Kerangka kerja ini dirancang untuk melahirkan perubahan paradigma dan menanamkan kebiasaan WSH yang baik pada semua individu di tempat kerja. Ini diabadikan dalam tiga prinsip utama kerangka kerja, dengan manajemen risiko menjadi landasan (Teo, Ofori, Tjandra, \& Kim, 2016). Prinsip dasar pertama dalam kerangka kerja baru ini adalah untuk menghilangkan atau mengurangi risiko sebelum risiko itu dibuat dan tidak hanya menerima atau menanggung risiko yang ada. Oleh karena itu, semua pemangku kepentingan di tempat kerja perlu melakukan penilaian risiko untuk membantu mengidentifikasi risiko dan sumbernya, tindakan yang harus 
diambil untuk menghilangkan atau mengurangi risiko dan pihak-pihak yang bertanggung jawab untuk melakukannya (Bloomberg, 2019).

Prinsip pertama yang mendari kerangka kerja baru adalah untuk menghilangkan atau memitigasi risiko sebelum risiko diciptakan dan tidak hanya menerima atau menanggung risiko yang ada. Semua dengan demikian para pemangku kepentingan di tempat kerja perlu melakukan penilaian risiko untuk membantu mengidentifikasi risiko dan sumbernya, tindakan yang harus diambil untuk menghilangkan atau mengurangi risiko dan pihak yang bertanggung jawab untuk melakukannya. Prinsip kedua adalah untuk kepemilikan industri yang lebih besar.

Tingkat kesadaran dan kewaspadaan industri yang meningkat terhadap WSH telah terjadi dalam kinerja WSH yang lebih baik sejak 2005. Untuk mempertahankan peningkatan WSH, pola pikir yang benardan diperlukan sikap di tempat kerja untuk memperkuat pentingnya dan penekanan pada WSH. Ini akan mencegah kepuasan berpuas diri dari pencapaian yang telah dicapai. Dengan demikian, dalam WSH 2018, hasil yang diinginkan memiliki progresif dan meresap budaya keselamatan dan kesehatan telah dibuat eksplisit dan ditambahkan ke tiga strategis hasil (Ivan Krstić dan Ana Stojković., 2019).

\section{Sistem Manajemen Keselamatan di Australia}

Undang-undang Kesehatan dan Keselamatan Kerja (K3) Penambangan di Australia umumnya dipandang sebagai regulasi paling progresif di dunia. Undangundang ini didasarkan pada tugas perawatan, prinsip-prinsip manajemen risiko dan perwakilan tenaga kerja, dengan tanggung jawab utama untuk penyediaan tempat kerja yang aman yang berada dengan operator situs tambang. Inspektur pemerintah bertindak sebagai penegak peraturan dan mentor yang mendorong kinerja kesehatan dan keselamatan yang baik. Protokol penegakan umumnya berbasis risiko, dengan tindakan yang didefinisikan oleh tingkat dan kedekatan risiko.

Australia menerapkan standar AS/NZ 4801 sebagai pedoman sistem keselamatan. Pada tahun 2018, dicanangkan bahwasanya Standar AS/NZ 4801 yang telah diterapkan akan diganti dengan standar interasional yakni ISO 4501. Namun, dalam implementasinya di Australia belum tampak hingga saat ini (Weller \& O’Neill, 2014).

Sistem manajemen keselamatan pertambangan di Australia memiliki dua Standar yang mencakup Kesehatan Kerja dan Sistem Manajemen Keselamatan, sebagai berikut :

1. AS / NZS 4801: 2001 Kesehatan dan keselamatan kerja sistem manajemen Spesifikasi dengan panduan untuk digunakan,

2. AS / NZS 4804: 2001 Kesehatan dan keselamatan kerjasistem manajemen pedoman umum tentang prinsip-prinsip,sistem dan teknik pendukung (Stemn, Bofinger, Cliff, \& Hassall, 2019). 


\section{Sistem Manajemen Keselamatan di Malaysia}

Malaysia menerapkan sistem manajemen keselamatan yang diakui secara internasional yakni OHSAS 18001 (Occupational Health and Safety Assesment Series 18001). Dengan mengimplementasikan OHSAS 18001 berarti organisasi telah memiliki kerangka acuan yang pasti bagi efektifitas manajemen K3 seperti pendeteksian adanya bahaya yang timbul dari proses produksi, serta pengawasan terhadap kegagalan manajemen.

Elemen sentral OHSAS 18001 adalah manajemen risiko. Manajemen risiko mencakup aspek-aspek seperti penentukan konteks, identifikasi risiko, analisa risiko, evaluasi risiko, pengendalian risiko, komunikasi dan proses monitoring dan kaji ulang. Jadi, sebelum mengembangkan sistem manajemen keselamatan dan kesehatan kerja OHSAS 18001 hendaknya dipelajari terlebih dahulu manajemen risiko (Abidin \& Hasibuan, 2019).

OHSAS 18001 ditujukan kepada perusahaan yang ingin memiliki sistem manajemen keselamatan dan kesehatan kerja yang berguna menghilangkan atau mengurangi tingkat risiko yang menimpa karyawan atau pihak-pihaklain yang terkena dampak operasional perusahaan, menerapkan dan memelihara sistem manajemen keselamatan dan kesehatan kerja secara kontinyu serta melalukan sertifikasi atau self assessment (Awang, Baharudin, \& Saliluddin, 2019).

\section{Kesimpulan}

Sistem manajemen keselamatan di beberapa negara yakni Indonesia, Korea Selatan, Singapura dan Australia. Perbedaan yang signifikan terdapat pada penerapan yang dilakukan dan peraturan pemerintah mengenai sistem keselamatan di negaranegara ini. Untuk Indonesia dan Singapura, sistem manajemen keselamatan wajib diimplementasikan di perusahaan industri, sedangkan untuk negara seperti Korea selatan sistem manajemen keselamatannya bersifat voluntary dengan kata lain sistem manajemen keselamatan diterapkan secara sukarela oleh industri. Di Australia, sistem manajemen keselamatan menerapkan standar dan referensi dalam industri. Di negara seperti Australia, Korea Selatan dan Malaysia, sistem manajemen keselamatan negara tersebut disesuaikan kembali dengan kebutuhan industri.

\section{BIBLIOGRAFI}

Abidin, Jainal, \& Hasibuan, A. F. (2019). Pengaruh Dampak Pencemaran Udara Terhadap Kesehatan Untuk Menambah Pemahaman Mayarakat Awam Tentang Bahaya Dari Polusi Udara. Prosiding SNFUR, 4, 2-3.

Awang, Noorhasimah, Baharudin, Mohd Rafee, \& Saliluddin, Suhainizam Muhamad. (2019). Occupational Safety and Health Management System (OSHMs): Perception and Safety Satisfaction among Employees in Certified Organisations in Klang Valley. Int. J. Educ. Res., 7(7), 37-45.

Bloomberg, Philantroepis. (2019). Tinjauan Singkat Pendekatan Keselamatan Jalan di 
Singapura. Global Road Safety Facility.

G.Sumarno, A. Winars. dan M. Fardha. (2018). Analisis Implementasi Sistem Manajemen Keselamatan Pertambangan Batubara di Plant Support Equipment Departement. Jurnal Rekayasa Teknologi Industri.

Ivan Krstić dan Ana Stojković. (2019). Integrated Safety Management System. Safety Engineering. 9(1), 29-36.

Kementerian Kesehatan Republik Indonesia. (2014). Peraturan Menteri Kesehatan Republik Indonesia Nomor 56 tahun 2014 tentang Klasifikasi dan Perizinan Rumah Sakit.

Kim, Kwangsoo, \& Kim, Myungsik. (2012). RFID-based location-sensing system for safety management. Personal and Ubiquitous Computing, 16(3), 235-243.

Lee, Sung woon, Kim, Kyu hwan, \& Kim, Tae gu. (2012). Current situation of certification system and future improvements of the occupational health and safety management system for loss prevention in Korea-Focused on KOSHA 18001. Journal of Loss Prevention in the Process Industries, 25(6), 1085-1089.

Markkanen, Pia K. (2004). Occupational safety and health in Indonesia= Keselamatan dan kesehatan kerja di Indonesia. International Labour Organization.

S.Suhardianto. (2009). Analisis Penerapan Sistem Manajemen Keselamatan Pertambangandi PT. Citra Tobindo Sukses Perkasa. Tesis. Fakultas Teknologi Mineral. UPN Veteran Yogyakarta.

Setianingrum, Astien, \& Susilowati, Indri Hapsari. (2020). Analisis Manajemen Risiko Keselamatan di Perusahaan Kontraktor Pertambangan Batubara Site XYZ Berdasarkan Sistem Manajemen Keselamatan Pertambangan Mineral dan Batubara. Pro Health Jurnal Ilmiah Kesehatan, 2(1).

Sholihah, Qomariyatus. (2018). Implementasi Sistem Manajemen K3 Pada Konstruksi Jalan Sebagai Upaya Pencegahan Kecelakaan Kerja. Buletin Profesi Insinyur, 1(1), $25-31$.

Situmorang, James Rianto. (2012). Pemanfaatan internet sebagai new media dalam bidang politik, bisnis, pendidikan dan sosial budaya. Jurnal Administrasi Bisnis, $8(1)$.

Stemn, Eric, Bofinger, Carmel, Cliff, David, \& Hassall, Maureen E. (2019). Examining the relationship between safety culture maturity and safety performance of the mining industry. Safety Science, 113, 345-355.

Suryosagoro, Sabuaji Brastowo, Laksito, Budi, \& Sugiyarto, Sugiyarto. (2013). Analisis Kondisi Sistem Manajemen Keselamatan Dan Kesehatan Kerja (SMK3) Pada Proyek Konstruksi Menuju Peraturan Pemerintah Nomor 50 Tahun 2012 (Studi Kasus: Proyek Alila Suite SCBD oleh PT. Hutama Karya (Persero)). Matriks 
Overview Analisis Sistem Manajemen Keselamatan pada Industri Pertambangan

Teknik Sipil, 1(4), 496.

Teo, Ai Lin Evelyn, Ofori, George, Tjandra, Imelda Krisiani, \& Kim, Hanjoon. (2016). Design for safety: theoretical framework of the safety aspect of BIM system to determine the safety index. Construction Economics and Building, 16(4), 1-18.

Weller, Sally, \& O'Neill, Phillip. (2014). An argument with neoliberalism: Australia's place in a global imaginary. Dialogues in Human Geography, 4(2), 105-130. 